IZA DP No. 7172

Why Some Firms Export? An Empirical Analysis for Manufacturing Firms in the MENA Region

Ali Fakih

Pascal L. Ghazalian

January 2013 


\title{
Why Some Firms Export? An Empirical Analysis for Manufacturing Firms in the MENA Region
}

\author{
Ali Fakih \\ Lebanese American University \\ and IZA \\ Pascal L. Ghazalian \\ University of Lethbridge \\ Discussion Paper No. 7172 \\ January 2013 \\ IZA \\ P.O. Box 7240 \\ 53072 Bonn \\ Germany \\ Phone: +49-228-3894-0 \\ Fax: +49-228-3894-180 \\ E-mail: iza@iza.org
}

Any opinions expressed here are those of the author(s) and not those of IZA. Research published in this series may include views on policy, but the institute itself takes no institutional policy positions. The IZA research network is committed to the IZA Guiding Principles of Research Integrity.

The Institute for the Study of Labor (IZA) in Bonn is a local and virtual international research center and a place of communication between science, politics and business. IZA is an independent nonprofit organization supported by Deutsche Post Foundation. The center is associated with the University of Bonn and offers a stimulating research environment through its international network, workshops and conferences, data service, project support, research visits and doctoral program. IZA engages in (i) original and internationally competitive research in all fields of labor economics, (ii) development of policy concepts, and (iii) dissemination of research results and concepts to the interested public.

IZA Discussion Papers often represent preliminary work and are circulated to encourage discussion. Citation of such a paper should account for its provisional character. A revised version may be available directly from the author. 


\section{ABSTRACT
Why Some Firms Export? An Empirical Analysis for Manufacturing Firms in the MENA Region

This paper analyzes the exporting behaviour of manufacturing firms located in the Middle East and North Africa (MENA) region using data from the World Bank's Enterprise Surveys Database. It specifically examines the factors that determine the probability of exporting and the export intensity of these firms. The empirical specification is represented through a country-specific effect model and through a model with country variables. The empirical results reveal significant positive effects of private foreign ownership, information and communication technology, and firm size on the probability of exporting and on export intensity of MENA manufacturing firms. Government ownership and the relative labour compositions of firms in terms of skilled production workers and in terms of non-production workers tend to exert negative effects on firms' propensity to export. The empirical results from the model with country variables underscore the enhancing effects of national economic development factors on the probability of exporting and on export intensity. Also, they indicate that the propensity to export of these firms decreases with larger domestic market size. The empirical analysis reveals considerable variations in the effects of the determining factors when carrying out the estimation for individual countries.

JEL Classification: F1, F4, F14

Keywords: exporting decision, export intensity, probit model, fractional logit model, MENA region

Corresponding author:

Pascal L. Ghazalian

Department of Economics

University of Lethbridge

Lethbridge, Alberta, T1K 3M4

Canada

E-mail: pascal.ghazalian@uleth.ca 
IZA Discussion Paper No. 7172

January 2013

\section{NON-TECHNICAL SUMMARY}

Considerable efforts have been exerted by policy-makers in the Middle East and North Africa (MENA) region over the past decades to help firms to expand their activities beyond the national borders (O'Sullivan et al., 2011). This is because export expansion is commonly perceived to induce economic growth as exporters respond to the demand from foreign markets (Bernard and Jensen, 1999). However, MENA countries continue to score lower grades through various indicators of international competiveness in export markets compared to other developing countries (Ahmed, 2010; O'Sullivan et al., 2011). In this context, assessing the factors that determine the exporting behaviour of firms is an important input for policies intended to improve the exporting performance of domestic sectors. This study contributes to the existing literature by investigating the determinants of the probability of exporting and those of export intensity of manufacturing firms in the MENA region. Specifically, we examine the role of ownership type, firm size, firm age, information and communication technology (ICT) use, and labour compositions. Also, we test for the role of macroeconomic variables in explaining the exporting behaviour of firms. These variables depict national economic and financial development levels, market size, and business characteristics. We model the probability of exporting using the probit model and the export intensity using the fractional logit model (Papke and Wooldridge, 1996). We use a micro-level dataset covering manufacturing firms in the MENA region. This dataset is sourced from the World Bank's Enterprise Surveys Indicator database.

The main results reveal significant positive effects of private foreign ownership, ICT use, and firm size on the probability of exporting and on export intensity. Government ownership and relative labour compositions of firms in terms of skilled production workers and in terms of non-production workers tend to exert negative effects on firms' propensity to export. The negative effects of labour compositions is consistent with the neo-classical trade theory, given that MENA countries are considered to be plausibly more abundant in unskilled workers compared to several exporting destinations. The macroeconomic variables reflect the enhancing effect of national economic development on firms' export performance. Meanwhile, the results show that a larger domestic market size decreases the propensity of firms to export. MENA manufacturing firms are not large in general. Consequently, larger domestic markets would satisfy these firms and would not compel them to seek foreign markets for their products. The results from this study have important policy implications. The enhancing effects of private foreign ownership on firms' exporting activities suggest that industrial growth and international competitiveness can be improved through policies that facilitate foreign investment in the MENA manufacturing sector. The negative effect of government ownership for the exporting behaviour of firms (particularly in Algeria and Syria) suggests that privatization policies could be adopted through the manufacturing sector. The results also underline the positive effects of policies that promote productivity and economies of scale in production. They also reveal the significant role of policies that support the adoption and dissemination of ICT in realizing international competitiveness. The results confirm the positive implications of growth-promoting macroeconomic policies for the exporting performance of the manufacturing sector in the MENA region. 


\section{Introduction}

A wide range of empirical studies has analyzed the factors that determine the exporting behaviour of manufacturing firms in many countries and regions, ${ }^{1}$ but detailed investigations for firms located in the Middle East and North Africa (MENA) region remain scarce in the literature. ${ }^{2}$ Indeed, considerable efforts have been exerted by policy-makers in the MENA region over the past few decades to help manufacturing firms to expand their activities beyond national borders (O’Sullivan et al., 2011). This is because export expansion could eventually lead to higher industrial growth rates as exporters respond to the demand from foreign markets (Bernard and Jensen, 1999). However, MENA countries continue to score lower grades through various indicators of international competiveness in export markets compared to other developing countries (Ahmed, 2010; O’Sullivan et al., 2011). Thus, determining the implications of the factors that influence the exporting behaviour of manufacturing firms in the MENA region is essential for policies intended to enhance industrial growth and international competitiveness. ${ }^{3}$

The empirical literature has regularly demonstrated that exporting firms are characterized by larger size than non-exporters (e.g., Roberts and Tybout, 1997; Bernard and Jensen, 2004; Alvarez

\footnotetext{
1 The empirical literature covers the analysis of the factors that determine the exporting behaviour of manufacturing firms in developed countries such as, Germany (Bernard and Wagner, 2001; Wagner, 2008), Italy (Castellani, 2009), Japan (Head and Ries, 2003), Spain (Blanes-Cristobal et al., 2008), the United Kingdom (Greenaway et al., 2007; Kneller et al., 2008), and the United States (Bernard and Jensen, 1999, 2004). Some empirical studies carried out the analysis for manufacturing firms in some developing countries such as, Argentina (Ottaviano and Martincus, 2011), Chile (Alvarez and López, 2005), Colombia (Roberts and Tybout, 1997), India (Sharma and Mishra, 2011), and Turkey (Yasar et al., 2006).

${ }^{2}$ It is worth noting the study by Clerides et al. (1998) which analyzed the causal link between exporting activities and productivity for manufacturing firms located in Morocco, in addition to those located in Colombia and Mexico. The findings indicate that exporting firms in these countries are more efficient than those that do not export.

${ }^{3}$ Statistical figures from the World Bank database indicate that the value added of the manufacturing sector in the MENA region (measured as a percentage of GDP) has slightly decreased from $12.2 \%$ in 1990 to $10.8 \%$ in 2007 . The statistics also indicate that exports of manufactured products of the MENA region represented $24.5 \%$ of total merchandise exports in 2009. The corresponding country-level statistics reveal significant variations across MENA countries, particularly between oil-rich and other MENA countries. For example, the percentage of exports of manufactured products from total merchandise exports was 1.6\% for Algeria and 8.1\% for Saudi Arabia compared to 43.8\% for Egypt and 72.5\% for Lebanon.
} 
and López, 2005; Bernard et al., 2007). ${ }^{4}$ Firm size proxies for productivity since firms with lower marginal costs are likely to experience faster growth, and it also captures economies of scale which promote exporting activities (Bernard and Jensen, 2004; Ottaviano and Martincus, 2011). Many empirical studies revealed the positive effects of productivity of firms on their propensity to export using direct measures such as total factor productivity indicators (e.g., Bernard and Jensen, 2004; Alvarez and López, 2005). ${ }^{5}$ The empirical literature has also underlined positive implications of foreign (multinational) ownership for exporting activities of manufacturing firms (e.g., Aitken et al., 1997; Bernard and Jensen, 2004; Alvarez and López, 2005; Greenaway et al., 2007). Multinational firms are expected to have more information about foreign markets. They normally have stronger business relationships with firms located in foreign countries, particularly those belonging to the same multinational corporation. Also, they have the advantage of using their multinational distribution networks which facilitate their exporting activities. Few studies found positive effects of firm's age on the propensity to export (e.g., Roberts and Tybout, 1997). This is consistent with the argument that older firms are more efficient because inefficient firms tend to exit competitive markets over time. However, other studies did not find any statistical evidence (e.g., Ottaviano and Martincus, 2011) or reported negative effects (e.g., Alvarez and López, 2005).

Bernard and Jesnen (1995) examined the role of labour composition in determining the propensity to export of manufacturing firms in the United States. They found that firms that have higher ratios of non-production workers have higher propensity to export. ${ }^{6}$ Bernard and Jesnen (2004) found similar results through their benchmark empirical model. However, this effect

\footnotetext{
${ }^{4}$ Wagner (2001) analyzed the exporting behaviour of German firms and found that the largeness of firms is not a critical factor for firms to be engaged in exporting activities.

${ }^{5}$ This is consistent with the self-selection hypothesis where more productive firms select themselves to carry out exporting activities. The empirical literature also analyzed the alternative effects expressed through the learning-byexporting hypothesis. The latter implies that exporting activities improve productivity and enhance the flow of information from foreign markets. Some empirical studies found some empirical evidence that supports this hypothesis (e.g., Alvarez and López, 2005; Van Biesebroeck, 2005). However, many other studies did not find such evidence (e.g., Roberts and Tybout, 1997; Bernard and Jensen, 1999; Bernard and Wagner, 2001).

${ }^{6}$ Bernard and Jensen (1995) also found that exporting firms have higher capital-to-labour ratio.
} 
disappeared when using a fixed effect model. Bernard and Jesnen (2004) argued that firms with better quality of labour are expected to produce output with higher value-to-weight ratio and, hence, would be more inclined to enter the export market. Moreover, based on the argument of Bernard et al. (2006), manufacturing firms in developed countries which are more skill-intensive and capitalintensive in production are expected to have higher propensity to export. This argument is in accordance with the neo-classical trade theory where firms in developed countries would export products that are consistent with the comparative advantage of developed countries. Alvarez and López (2005) found that exporting firms in Chile are also characterized by higher levels of skillintensity in production compared to non-exporters. These results disagree with the comparative advantage of Chile which is relatively abundant in unskilled labour. Finally, it can be noted that firms with higher ratios of non-production workers are arguably expected to have better managerial and organizational assets which can facilitate the entry into foreign markets. ${ }^{7}$

In this paper, we examine the factors that determine the probability of exporting and the export intensity of manufacturing firms located in the MENA region using data sourced from the World Bank’s Enterprise Surveys Database. This database covers a comprehensive and comparable source of firm-level data through many MENA countries. The methodology used in this study involves the analysis of firms’ export probability through a probit model, and the analysis of firms’ export intensity through a fractional logit model developed by Papke and Wooldridge (1996). Our paper contributes to the existing literature by providing new evidence on the determinants of exporting behaviour of manufacturing firms in the MENA region. Specifically, we examine the role of firm characteristics such as, ownership type (foreign ownership, government ownership), firm

\footnotetext{
7 The empirical literature has also examined the implications of many other factors on firms' export decision such as firms' financial health (Greenaway et al., 2007), labour training (Ottaviano and Martincus, 2011), Research and Development (R\&D) intensity (Wagner, 2001), and credit constraints (Minetti and Zhu, 2011). Also, several studies analyzed the implications of prior exporting experience of firms for their decision to export using annual firm-level data (e.g., Roberts and Tybout, 1997; Bernard and Wagner, 2001; Ottaviano and Martincus, 2011).
} 
size, firm age, Information and Communication Technology (ICT) depicted through the use of the Internet, and labour composition depicted through the proportions of skilled production workers and non-production workers. Also, we test for the role of macroeconomic variables of the MENA countries in explaining the exporting behaviour of firms. These variables depict national economic and financial development levels, national market size, and national business characteristics.

The main results indicate that private foreign ownership, ICT use, and firm size have significant positive effects on the probability of exporting and on the export intensity of manufacturing firms in the MENA region. The relative labour compositions of firms in terms of skilled production workers and in terms of non-production workers tend to exert negative effects on firms' propensity to export. The results provide some evidence on the reducing effects of government ownership on the probability of exporting and on export intensity of firms. The results from the model with country variables underscore the enhancing effects of national economic development factors on firms' propensity to export. Also, they indicate that the probability of exporting and the export intensity of these firms decrease with larger domestic market size. Finally, the empirical analysis for individual MENA countries reveals considerable variations in the effects of firm characteristics on the exporting behaviour of firms.

The remainder of the paper is organized as follows. Section 2 presents the data used along with descriptive statistics. Section 3 provides a description of the methodology used to analyze firms' decision to export and firms' export intensity. Section 4 presents and discusses the empirical results. Section 5 provides concluding remarks.

\section{Data}

We use a micro-level dataset covering manufacturing firms in the MENA region. This dataset is sourced from the World Bank's Enterprise Surveys Indicator Database. This survey collects information on a sample of private enterprises in more than 100 countries for the period between 
2002 and 2010. It represents a comprehensive source of firm-level data in emerging and developing countries. It contains information on various aspects of the business environment such as, access to finance, corruption, workforce characteristics, innovation and technology, and trade. The relevant survey data used in this paper covers 4386 manufacturing firms located in eight Arab countries in the MENA region (Algeria, Egypt, Jordan, Lebanon, Morocco, Oman, Syria, and Yemen). ${ }^{8}$ It should be noted that one of many advantages of using this survey is that the questions are identical through firms across all countries.

The survey provides information on whether a firm exports or not. This is depicted through a binary variable which equals one when a firm has exporting activities and zero otherwise. This survey also provides data on the intensity of exporting, which is equal to export values over total sales. The explanatory variables include ownership type (foreign ownership and government ownership), firm size which is measured by the number of employees, firm age which is measured by the number of years since the establishment of the firm. They also include a variable depicting the firm use of the Internet in communicating with its clients and in sourcing information. The characteristics of firms' labour composition, represented through the percentage of skilled production workers from total production workers and through the percentage of non-production workers from total workers, are also included in the regressions. The empirical model with macroeconomic variables includes Gross Domestic Product (GDP) which depicts national market size, and GDP per capita (GDPC) which depicts national economic development level. It also includes national indicators on financial development level and business environment. The

\footnotetext{
${ }^{8}$ The survey years/fiscal years are: 2002/2001 and 2007/2006 for Algeria's firms, 2007/2005 and 2008/2007 for Egypt's firms, 2006/2006 for Jordan’s firms, 2006/2004 and 2009/2008 for Lebanon’s firms, 2007/2005 for Morocco’s firms, 2003/2002 for Oman's firms, 2003/2002 and 2009/2008 for Syria’s firms, and 2010/2009 for Yemen’s firms. The manufacturing sectors are classified as: chemicals and pharmaceuticals, electronics, food, garments, leather, metals and machinery, non-metallic and plastic materials, textiles, wood and furniture, and other manufacturing.
} 
macroeconomic data are taken from the World Development Indicators (WDI) database of the World Bank.

Table 1 presents summary statistics of the variables used in the empirical analysis. The first panel shows the results for the dependent variables. They indicate that around $36 \%$ of the manufacturing firms in the sample exported directly or indirectly. The average export intensity in the sample implies that around 15\% of the output of the MENA region manufacturing firms were sold in foreign markets. The second panel shows the results for the explanatory variables. We find that the percentage of private foreign ownership has an average of around $4 \%$ in the sample whereas the percentage of government ownership has an average of around $2.5 \%$ in the sample. These averages are associated with relatively large standard deviations. The surveyed manufacturing firms have on average around 136 full-time workers. The average age of firms in the sample is around 21 years. It is interesting to note that around $39 \%$ of firms in the sample use the Internet to communicate with clients and to source information. Also, the percentage of skilled production workers from total production workers and the percentage of non-production workers from total employment have an average of around 59\% and 23\% in the sample, respectively.

\section{Empirical Methodology}

The primary objective of this study is to examine the determinants of the decision to export and the export intensity of manufacturing firms in the MENA region using firm-level data.

\subsection{Probit Model for Decision to Export}

We model the probability of exporting using a probit model. Let $H_{j}^{*}$ denote the benefits accruing to a given firm $j(j=1, \ldots, \mathrm{J})$ located in country $c(c=1, \ldots, \mathrm{C})$ from having exporting activities. The benchmark specification can be represented as: 


$$
H_{j}^{*}=X_{j} \beta+Z_{c} \delta+\varepsilon_{j}
$$

where $X_{j}$ represents a vector of variables depicting firm characteristics, $Z_{c}$ represents a vector of variables depicting the national characteristics of country $c$ in which firm $j$ is located, and $\varepsilon_{j}$ is the stochastic error term. This benchmark specification can be alternatively designed using countryspecific effects. ${ }^{9}$ The variable $H_{j}^{*}$ is not observed since it is a latent variable. Instead, we observe the firm's exporting decision. Hence, we define the following probit rule:

$$
H_{j}= \begin{cases}1 & \text { for } H_{j}^{*} \geq 0 \\ 0 & \text { for } H_{j}^{*}<0\end{cases}
$$

where $H_{j}$ is a binary variable which equals one when firm $j$ is engaged in exporting activities and zero otherwise. Let $\Phi(\cdot)$ depict the cumulative standard normal distribution function. Then, the probit regression model can be represented as:

$$
E\left(H_{j} \mid X_{j}, Z_{c}\right)=\Phi\left(X_{j} \beta+Z_{c} \delta\right)
$$

\subsection{Fractional Logit Model for Export Intensity}

A firm's export intensity is defined as the fraction of the total value of exports from the total value of sales. Let $I_{j}$ denote the export intensity of a given firm $j$, where $I_{j} \in[0,1]$. The seminal fractional logit model of Papke and Wooldridge (1996) is used to take into account the specific characteristics of the dependent variable. ${ }^{10}$ This model is given by:

$$
E\left(I_{j} \mid W_{j}\right)=G\left(W_{j} \theta\right)
$$

\footnotetext{
${ }^{9}$ In this case, we have $H_{j}^{*}=X_{j} \beta+D_{c} \delta+\varepsilon_{j}$, where $D_{c}$ depicts a vector of country-specific binary variables.

${ }^{10}$ The estimation model of Papke and Wooldridge (1996) is designed to take into account the bounded nature of fractional dependent variables between zero and one. These boundaries are established by definition and not by censoring (Wagner, 2001).
} 
where $W_{j}$ and $\theta$ represent the vector of explanatory variables and the corresponding vector of parameters, respectively, and where $0 \leq G\left(W_{j} \theta\right) \leq 1$ is a given non-linear function. Papke and Wooldridge (1996) advocated the fractional logit model estimated through a Quasi-Maximum Likelihood Estimator (QMLE) which maximizes the Bernoulli log-likelihood function of:

$$
l_{j}(\theta)=I_{j} \ln \left[G\left(W_{j} \theta\right)\right]+\left(1-I_{j}\right) \ln \left[1-G\left(W_{j} \theta\right)\right] \text {, }
$$

where $G(\cdot)$ is represented through the cumulative distribution function of the logistic distribution. ${ }^{11}$

As shown in Papke and Wooldridge (1996), the estimated parameters through the aforementioned QMLE are consistent regardless of the distribution of $I_{j}$ conditional on $W_{j}$, provided that equation (4) holds (see Gourieroux et al., 1984), and they have satisfactory efficiency properties. The "sandwich" formula of the variance-covariance matrix indicates robustness to arbitrary heteroskedasticity and correlation between residuals (see Gourieroux et al., 1984).

Following Papke and Wooldridge (1996), the fractional logit model assumes that the expected value of $I_{j}$, conditional on a vector of firm-specific variables $X_{j}$ and on a vector of country-specific variables $Z_{j}$, is given by:

$$
E\left(I_{j} \mid X_{j}, Z_{c}\right)=G\left(X_{j} \alpha+Z_{c} \gamma\right)
$$

where $G\left(X_{j} \alpha+Z_{c} \gamma\right)=\exp \left(X_{j} \alpha+Z_{c} \gamma\right) /\left[1+\exp \left(X_{j} \alpha+Z_{c} \gamma\right)\right]$ is the cumulative distribution function of the logistic distribution. ${ }^{12}$ The marginal effects are evaluated using the estimated

\footnotetext{
11 The parameters are estimated by solving the maximization problem $\underset{\theta}{\operatorname{Max}} \sum_{j} l_{j}(\theta)$.

${ }^{12}$ Consider a continuous variable $x_{j} \in X_{j}$ with a corresponding parameter $a \in \alpha$. The marginal effect is represented by $\partial E\left(I_{j} \mid X_{j}, Z_{c}\right) / \partial x_{j}=a g\left(X_{j} \alpha+Z_{c} \gamma\right)$, where $g\left(X_{j} \alpha+Z_{c} \gamma\right)=\exp \left(X_{j} \alpha+Z_{c} \gamma\right) /\left[1+\exp \left(X_{j} \alpha+Z_{c} \gamma\right)\right]^{2}$. The effects of country variables can be similarly depicted. Consider a binary variable depicted by $b_{j} \in X_{j}$. We have $E\left(I_{j} \mid \tilde{X}_{j}, Z_{c}, b_{j}=1\right)-E\left(I_{j} \mid \tilde{X}_{j}, Z_{c}, b_{j}=0\right)$, where $\tilde{X}_{j}$ equals $X_{j}$ excluding $b_{j}$.
} 
parameters $\hat{\alpha}$ and $\hat{\gamma}$ at the mean values of the explanatory variables throughout the empirical investigation.

Papke and Wooldridge (1996) method is a one-step approach which implies that the decision to export and the level of exports are not formulated separately in two different steps. Hence, firms determine the profit maximizing level of exports, which can be zero, in one-step (Wagner, 2001, 2008). ${ }^{13}$ Through the empirical investigation, the fractional logit model is alternatively estimated using country-specific effects. ${ }^{14}$

\section{Empirical Results}

\subsection{Firms’ Decision to Export}

This section examines the determinants of the probability of firms in the MENA region to export using the probit estimator. Table 2 reports the estimated coefficients and the corresponding marginal effects. Column (1) presents the results from a probit model with country-specific effects. The results reveal a positive and statistically significant effect of private foreign ownership on MENA manufacturing firms’ probability to export. They indicate that an increase in private foreign ownership share by 10 percentage points induces an increase in the probability to export by 3.1 percentage points. These results are consistent with those found in some previous studies (e.g., Aitken et al., 1997; Bernard and Jensen, 2004; Alvarez and López, 2005; Greenaway et al., 2007). The estimated coefficient on the government ownership variable is negative but it is not statistically significant.

\footnotetext{
${ }^{13}$ Wagner (2001) introduced the fractional logit model into the empirical literature that estimates the determinants of the exporting behaviour of firms. He emphasized the econometric appropriateness of this model and discussed the various issues when using the alternative Heckman two-step model. The latter implies that the decision to export and the decision on how much to export, given that the decision to export has been taken, are empirically formulated separately.

${ }^{14}$ In this case, we have $E\left(I_{j} \mid X_{j}, D_{c}\right)=G\left(X_{j} \alpha+D_{c} \gamma\right)$, where $D_{c}$ depicts a vector of country-specific binary variables.
} 
The results underscore a positive and statistically significant effect of firm size on the probability to export, in accordance with previous empirical literature (e.g., Aitken et al., 1997; Roberts and Tybout, 1997; Bernard and Jensen, 1999, 2004; Alvarez and López, 2005). The marginal effect indicates that an increase in firm size by 100 workers leads to an increase in the probability to export by 4.0 percentage points. The positive effect of firm size on the propensity to export proxies for the implications of higher productivity and economies of scales (Bernard and Jensen, 2004; Ottaviano and Martincus, 2011). As in Ottaviano and Martincus (2011), the estimated coefficient on firm age is not statistically significant.

The results highlight a positive and statistically significant effect of ICT use, depicted through the use of the Internet in communicating with the clients and in sourcing information, on the probability of firms to export. Specifically, firms using this type of ICT have considerably higher probability to export by around 33.7 percentage points. ${ }^{15}$ The ratio of skilled production workers is negative and statistically significant, implying that an increase in this ratio by 10 percentage points reduces the probability to export by 0.6 percentage points. This effect is small in magnitude and could be associated with some neo-classical trade theory (e.g., Heckscher-Ohlin) factors, following the discussion provided in Bernard et al. (2006) in the case of manufacturing firms in the United States. Most MENA countries are relatively less endowed in skilled workers compared to their export destination countries. Accordingly, they have a lower (higher) comparative advantage in exporting goods that use skilled (unskilled) workers more intensively. ${ }^{16}$ The estimated coefficient on the ratio of non-production workers is negative but it is not statistically significant. In comparison, some previous studies applied to firms in developed countries found that higher

\footnotetext{
${ }^{15}$ Equivalent results are obtained when using a variable depicting the firms' use of their own website as an alternative proxy for the ICT variable.

${ }^{16}$ Some studies examining the export performance of firms in developing countries (e.g., Chile) reported reverse relationships where exporting firms tend to use higher proportions of skilled workers than non-exporting firms (e.g., Alvarez and López, 2005).
} 
proportions of non-production workers are positively related to firms’ decision to export (e.g., Bernard and Jensen, 1999, 2004). ${ }^{17}$

Column (2) of Table 2 presents the estimated coefficients and the corresponding marginal effects from a probit model that includes country variables instead of country-specific effects. These variables cover national market size represented through the GDP, and national economic development level represented through the GDPC. ${ }^{18}$ The empirical results are generally equivalent to those presented in columns (1) but with few modifications. The estimated coefficient on the government ownership variable remains negative, but it becomes statistically significant at the 5\% level. The marginal effect implies that an increase in the share of government ownership by 10 percentage points reduces the probability of firms to export by 1.9 percentage points. Also, the effect of firm age becomes statistically significant at the $1 \%$ level, implying that an increase in firm age by 10 years induces an increase in the probability to export by 1.0 percentage point.

The estimated coefficient on the ratio of skilled production workers remains negative and statistically significant (now at the 1\% level). It implies moderately higher marginal effect (in absolute terms) where an increase in this ratio by 10 percentage points reduces the probability of firms to export by around 1.1 percentage points. Also, the estimated coefficient on the ratio of nonproduction workers remains negative but it becomes statistically significant at the $5 \%$ level. This result could be also explained through the neo-classical trade theory (e.g., Heckscher-Ohlin) factors given that MENA countries are plausibly less endowed with entrepreneurial and management workers compared to many of their export destination countries. Alternatively, this outcome could

\footnotetext{
${ }^{17}$ The corresponding estimation results from the probit specification that also includes sector-specific effects are presented in Table A1 of the Appendix. They are generally similar to those presented in Table 2. The estimated coefficient on the skilled production workers' ratio loses the statistical significance. Manufacturing sectors naturally differ in the intensity of skilled workers. Hence, the implications of inter-sectoral differences would be absorbed by the sector-specific effects.

${ }^{18}$ Country-specific effects could absorb the implications of inter-national variations through the dataset and, hence, could affect the magnitude of some estimated effects of firm-related variables. For example, government ownership prevails through several firms in Algeria and Egypt, but there are no firms in Lebanon with government ownership.
} 
also reflect inefficiencies in over-hiring non-production workers. The marginal effect reveals that an increase in the ratio of non-production workers by 10 percentage points reduces the probability of firms to export by 1.1 percentage points.

The estimated coefficient on the GDPC variable is positive and statistically significant at the 1\% level. It indicates that a higher national economic development level would facilitate the exporting activities of manufacturing firms in the MENA region. Specifically, a $10 \%$ increase in GDPC increases the probability of firms to export by around 0.8 percentage points. This result has important implications given the significant variations in GDPC through MENA countries. The estimated coefficient on the GDP variable is negative and statistically significant at the $1 \%$ level. It implies that smaller domestic markets compel MENA manufacturing firms to export to foreign destinations. Specifically, a decrease in the domestic market size by $10 \%$ would induce an increase in the probability of firms to export by 1.2 percentage points.

Finally, column (3) of Table 2 displays the estimated coefficients and the corresponding marginal effects when augmenting the previous specification by supplementary development variables covering a financial development indicator and a business freedom indicator. The estimated coefficients on these variables are statistically significant at the $1 \%$ level. An increase in these indicators by one unit leads to an increase in the probability of firms to export by 0.4 and 3.4 percentage points, respectively. These results contribute to the earlier literature that examined the effects of financial health of individual firms on their export performance (e.g., Greenaway et al., 2007; Minetti and Zhu, 2011) by underlining the role of national financial development levels in promoting the exporting activities of individual firms. The estimated coefficient on the GDPC variable loses its statistical significance since the effect of national economic development is being absorbed by these supplementary development indicators. 


\subsection{Firms’ Export Intensity}

This section examines the determinants of export intensity of manufacturing firms. Export intensity is defined as the fraction of the total value of exports from the total value of sales. The estimation is carried out using the fractional logit estimator of Papke and Wooldridge (1996). The estimated coefficients and the corresponding marginal effects for the empirical specification with countryspecific effects are displayed in column (1) of Table 3. The results reveal a positive and statistically significant effect of private foreign ownership on export intensity. The marginal effect indicates that an increase in foreign ownership by 10 percentage points leads to an increase in export intensity by 1.2 percentage points. Conversely, an increase in government ownership by 10 percentage points generates a decrease in export intensity by 0.8 percentage points. Also, an increase in firm size by 100 workers promotes an increase in export intensity by 0.7 percentage points.

The results indicate that the use of ICT induces an increase in export intensity by 10.3 percentage points. Unlike the results from the decision to export estimation, the ratio of skilled production workers does not have a statistically significant effect on export intensity. Meanwhile, the ratio of non-production workers exerts a negative and statistically significant effect on export intensity. An increase in this ratio by 10 percentage points reduces the export intensity by 0.9 percentage points. $^{19}$

The determinants of export intensity using the fractional logit estimator are examined through alternative empirical specifications which include country variables instead of countryspecific effects. The estimated coefficients and the corresponding marginal effects for a specification that includes the GDP and GDPC variables are displayed in column (2) of Table 3. The results indicate that a 10\% increase in GDPC leads to an increase in export intensity by 0.2

\footnotetext{
19 The corresponding estimation results from the fractional logit model that also includes sector-specific effects are displayed in Table A1 of the Appendix. They are qualitatively equivalent to those presented in Table 3. Some estimates become smaller in magnitude as sector-specific effects absorb some inter-sectoral variations through our dataset.
} 
percentage points and that a $10 \%$ increase in GDP induces a decrease in export intensity by 0.5 percentage points. Column (3) of Table 3 reports the results when adding the financial development and business freedom indicators to the previous specification. As in the probit analysis of firms' decision to export, the estimated coefficients on the financial development and business freedom variables are both positive and statistically significant at the $1 \%$ level, whereas the effect of GDPC on export intensity loses its statistical significance. An increase in the financial development and business freedom indicators by one unit promotes an increase in export intensity by 0.2 and 1.6 percentage points, respectively.

\subsection{Results for Individual MENA Countries}

Table 4 and Table 5 present the estimated coefficients and the corresponding marginal effects, respectively, from a probit model applied to individual MENA countries. ${ }^{20}$ The results generally reveal significant variations in the effects of the explanatory variables across MENA countries. The effect of private foreign ownership is found to be positive and statistically significant in the case of Egypt, Jordan, Morocco, and Yemen. The corresponding marginal effects indicate that an increase in private foreign ownership by 10 percentage points promotes an increase in the probability of firms to export in these countries by 4.0, 4.1, 2.4, and 4.5 percentage points, respectively. This effect is not found to be statistically significant for manufacturing firms located in other MENA countries. The reducing effect of government ownership is mainly emphasized in the case of Syria's manufacturing firms. This is where an increase in government ownership by 10 percentage points reduces the probability of firms to export by 5.9 percentage points. Also, government ownership perfectly predicts non-exporting manufacturing firms in the case of Algeria.

\footnotetext{
${ }^{20}$ The empirical analysis for individual MENA countries does not cover manufacturing firms located in Oman, which only make a total of 40 observations.
} 
The effect of firm size is positive and statistically significant for all MENA countries with the exception of Lebanon. It is found to be relatively higher in the case of Morocco and Syria where an increase in firm size by 100 workers raises the probability of firms to export by 16.3 and 17.0 percentage points, respectively. The effect of firm age is statistically significant in the case of Morocco and Syria. The marginal effects indicate that an increase in firm age by 10 years reduces the probability of Morocco’s firms to export by 11.0 percentage points but increases the probability of Syria’s firms to export by 3.0 percentage points.

The effect of ICT use is positive and statistically significant for all MENA countries with the exception of Morocco. It is particularly large in the case of Egypt and Jordan where the use of ICT induces an increase in the probability of firms to export by 41.0 and 49.2 percentage points, respectively. The estimated coefficients on the ratio of skilled production workers are not statistically significant for most MENA countries. An exception is found in the case of Syria where an increase in this ratio by 10 percentage points reduces the probability of firms to export by 1.5 percentage points. The estimated coefficients on the ratio of non-production workers are not statistically significant through the MENA countries.

Next, we examine the determinants of export intensity of manufacturing firms applied for individual MENA countries. Table 6 and Table 7 display the estimated coefficients and the corresponding marginal effects from the fractional logit estimator, respectively. Generally, the results are found to be in conformity with those derived from the probit analysis. The estimated coefficients on the private foreign ownership variable are found to be positive and statistically significant in the case of Egypt, Jordan, and Yemen. The corresponding marginal effects indicate that an increase in private foreign ownership by 10 percentage points raises the export intensity of firms in these countries by 1.2, 5.1, and 1.3 percentage points, respectively. Also, the results reveal 
that an increase in government ownership by 10 percentage points reduces export intensity of Syria’s manufacturing firms by 2.2 percentage points.

Firm size exhibits positive effects on export intensity of firms located in different MENA countries with the exception of Lebanon. For example, an increase in firm size by 100 workers raises the export intensity of manufacturing firms in Jordan and Morocco by 5.3 and 8.0 percentage points, respectively. Conversely, firm age has negative effects on export intensity of firms located in these two countries. The results highlight the positive effects of ICT use on export intensity for most MENA countries. For example, the marginal effects indicate that the use of ICT increases the export intensity of Egypt's and Jordan's firms by 16.4 and 27.1 percentage points, respectively. The effect of skilled production workers' ratio is not statistically significant through the MENA countries whereas non-production workers' ratio exerts negative and statistically significant effects on export intensity in the case of Morocco and Syria.

\section{Conclusion}

This study analyzes the determinants of the exporting behaviour of manufacturing firms in the MENA region through a probit model for the decision to export and through a fractional logit model for export intensity. The determinants cover firm characteristics such as foreign ownership, government ownership, firm size, firm age, labour characteristics, and ICT use. They also cover national characteristics which include market size, economic and financial development, and business freedom. The main results emphasize the significant positive effects of private foreign ownership, ICT use, and firm size on the probability of exporting and on export intensity. Government ownership and the relative labour compositions of firms in terms of skilled production workers and in terms of non-production workers tend to exert negative effects on firms' propensity to export. The negative effects of these labour compositions could be explained through some neoclassical trade theory given that the MENA countries are considered to be plausibly more abundant 
in unskilled workers compared to their exporting destinations. The macroeconomic variables reflect the enhancing effect of national economic development on firms' export performance. Meanwhile, the results show that larger domestic market size decreases the propensity of firms to export. MENA manufacturing firms are not large in general. Consequently, larger domestic markets would satisfy these firms and would not compel them to seek foreign markets for their products.

The results derived from the analysis of manufacturing firms in individual countries indicate a considerable heterogeneity in the effects of the explanatory variables on the decision to export and on export intensity. The main results emphasize the positive effect of foreign ownership for firms located in Egypt Morocco, Jordan, and Yemen. They also reveal an important negative effect of government ownership on the export performance of firms located in Algeria and in Syria. The results underscore positive effects of firm size and ICT use for firms' propensity to export through most MENA countries that are included in our study.

Finally, the results from this study have important policy implications. The enhancing effects of foreign ownership on firms' exporting activities suggest that industrial growth and international competitiveness can be improved through policies that facilitate foreign investment in the MENA manufacturing sector. These benefits can be realized in addition to the potential spillover effect that occurs from multinational firms to the domestic sector. The negative effect of government ownership for the exporting behaviour of Algeria's and Syria's firms suggests that privatization policies could be adopted through the manufacturing sector. The results also underline the positive effects of policies that promote productivity and economies of scale in production. They also reveal the significant role of policies that support the adoption and dissemination of ICT in realizing international competitiveness. The results confirm the positive implications of growthpromoting macroeconomic policies for the exporting performance of the manufacturing sector in the MENA region. 


\section{References}

Aitken, B., G. Hanson, and A. Harrison. 1997. "Spillovers, Foreign Investment, and Export Behavior”. Journal of International Economics, 43(1-2): 103-132.

Ahmed, M. 2010. “Trade Competitiveness and Growth in the MENA Region”. Published in: the World Economic Forum's Arab World Competitiveness Review, International Monetary Fund (IMF), Washington, DC.

Alvarez, R., and R.A. López. 2005. "Exporting and Performance: Evidence from Chilean Plants”. Canadian Journal of Economics, 38(4): 1384-1400.

Bernard, A.B., and J.B. Jensen. 1995. "Exporters, Jobs, and Wages in US Manufacturing: 19761987”. Brookings Papers on Economic Activity: Microeconomics: 67-112.

Bernard, A.B., and J.B. Jensen. 1999. “Exceptional Exporter Performance: Cause, Effect or Both?”. Journal of International Economics, 47(1): 1-25.

Bernard, A.B., and J.B. Jensen. 2004. “Why Some Firms Export?”. The Review of Economics and Statistics, 86 (2): 561-569.

Bernard, A.B., J.B. Jensen, S.J. Redding, and P.K. Schott. 2007. "Firms in International Trade”. Journal of Economic Perspectives, 21(3): 105-130.

Bernard, A.B., J.B. Jensen, and P.K. Schott. 2006. "Survival of the Best Fit: Exposure to LowWage Countries and the (Uneven) Growth of US Manufacturing Plants". Journal of International Economics, 68(1): 219-237.

Bernard, A.B., and J. Wagner. 2001. "Export Entry and Exit by German Firms”. Review of World Economics, 137(1): 105-123.

Blanes-Cristobal, J., M. Dovis, J. Milgram-Baleix, and A. Moro-Egido. 2008. "Do Sunk Exporting Costs Differ among Markets? Evidence from Spanish Manufacturing Firms”. Economic Letters, 101(2): 110-112.

Castellani, D. 2002. "Export Behavior and Productivity Growth: Evidence from Italian Manufacturing Firms”. Review of World Economics, 138(4): 605-628.

Clerides, S.K., S. Lach, and J.R. Tybout. 1998. "Is Learning by Exporting Important? MicroDynamic Evidence from Colombia, Mexico, and Morocco”. Quarterly Journal of Economics, 113(3): 903-947.

Gourieroux, C., A. Monfort, and A. Trognon. 1984. "Pseudo-Maximum Likelihood Methods: Theory”. Econometrica, 52(3): 681-700.

Greenaway, D., A. Guariglia, and R. Kneller. 2007. "Financial Factors and Exporting Decisions”. Journal of International Economics, 73(2): 377-395. 
Head, K., and J. Ries. 2003. "Heterogeneity and the FDI versus Export Decision of Japanese Manufacturers”. Journal of the Japanese and International Economies, 17(4): 448-467.

Kneller, R., M. Pisu, and Z. Yu. 2008. “Overseas Business Costs and Firm Export Performance”. Canadian Journal of Economics, 41(2): 639-669.

Minetti, R., and S.C. Zhu. 2011. "Credit Constraints and Firm Export: Microeconomic Evidence from Italy”. Journal of International Economics, 83(2): 109-125.

O’Sullivan, A., M.-E. Rey, and J.G. Mendez. 2011. "Opportunities and Challenges in the MENA Region”. MENA-OECD Investment Programme, Organization for Economic Cooperation and Development (OECD), Paris, France.

Ottaviano, G., and C.V. Martincus. 2011. “SMEs in Argentina: Who are the Exporters?”. Small Business Economics, 37(3): 341-361.

Papke, L.E., and J.M. Wooldridge. 1996. "Econometric Methods for Fractional Response Variables with an Application to 401(k) Plan Participation Rates”. Journal of Applied Econometrics, 11(4): 619-632.

Roberts, M., and J. Tybout. 1997. “An Empirical Model of Sunk Costs and the Decision to Export”. American Economic Review, 87(4): 545-564.

Sharma, C., and R.K. Mishra. 2011. "Does Export and Productivity Growth Linkage Exist? Evidence from the Indian Manufacturing Industry”. International Review of Applied Economics, 25(6): 633-652.

Van Biesebroeck, J. 2005. "Exporting Raises Productivity in Sub-Saharan African Manufacturing Firms”. Journal of International Economics, 67(2): 373-391.

Wagner, J. 2001. “A Note on the Firm Size - Export Relationship”. Small Business Economics, 17(4): 229-237.

Wagner, J. 2008. "Exports and Firm Characteristics - First Evidence from Fractional Probit Panel Estimates”. Working Paper Series in Economics, Leuphana University of Lüneburg, Lüneburg, Germany.

Yasar, M., C.H. Nelson, and R. Rejesus, 2006. "Productivity and Exporting Status of Manufacturing Firms: Evidence from Quantile Regressions”. Review of World Economics, 142(4): 675-694. 
Table 1: Descriptive Statistics

\begin{tabular}{l|cc}
\hline \hline & Mean & Standard deviation \\
\hline \hline Dependent variables & & \\
Exporting firm (binary variable) & 0.365 & 0.481 \\
Export intensity (value of exports/value of total sales) & 0.154 & 0.284 \\
& & \\
Explanatory variables & & \\
Foreign ownership (percentage) & 4.091 & 18.220 \\
Government ownership (percentage) & 2.574 & 15.339 \\
Firm size (total employment) & 135.537 & 336.924 \\
Firm age (years) & 21.360 & 17.061 \\
Firm use of ICT (binary variable) & 0.393 & 0.488 \\
Skilled/Total production workers & 0.589 & 0.288 \\
Non-production/Total employment & 0.227 & 0.179 \\
GDPC (current USD) & 2482.5 & 1512.5 \\
GDP (billions of current USD) & 95.6 & 58.0 \\
Financial development (national indicator) & 38.278 & 23.060 \\
Business freedom (national indicator) & 5.373 & 1.668 \\
\hline$N$ & & 4386 \\
\hline \hline
\end{tabular}


Table 2: Firms’ Decision to Export (Probit Model)

\begin{tabular}{|c|c|c|c|c|c|c|}
\hline & \multicolumn{2}{|c|}{$(1)$} & \multicolumn{2}{|c|}{$(2)$} & \multicolumn{2}{|c|}{ (3) } \\
\hline & Coefficients & $\begin{array}{c}\text { Marginal } \\
\text { effects }\end{array}$ & Coefficients & $\begin{array}{c}\text { Marginal } \\
\text { effects }\end{array}$ & Coefficients & $\begin{array}{c}\text { Marginal } \\
\text { effects }\end{array}$ \\
\hline Foreign ownership & $\begin{array}{c}0.876^{* * *} \\
(0.165)\end{array}$ & $\begin{array}{c}0.309 * * * \\
(0.058)\end{array}$ & $\begin{array}{c}0.775^{* * * *} \\
(0.131)\end{array}$ & $\begin{array}{c}0.285 * * * \\
(0.048)\end{array}$ & $\begin{array}{c}0.614 * * * \\
(0.133)\end{array}$ & $\begin{array}{c}0.226 * * * \\
(0.049)\end{array}$ \\
\hline Government ownership & $\begin{array}{l}-0.297 \\
(0.233)\end{array}$ & $\begin{array}{l}-0.105 \\
(0.082)\end{array}$ & $\begin{array}{c}-0.521^{* *} \\
(0.215)\end{array}$ & $\begin{array}{c}-0.192 * * \\
(0.080)\end{array}$ & $\begin{array}{c}-0.518 * * \\
(0.213)\end{array}$ & $\begin{array}{c}-0.190 * * \\
(0.079)\end{array}$ \\
\hline Firm size & $\begin{array}{c}0.114^{* * * *} \\
(0.026)\end{array}$ & $\begin{array}{c}0.040 * * * \\
(0.009)\end{array}$ & $\begin{array}{c}0.125^{* * *} \\
(0.027)\end{array}$ & $\begin{array}{c}0.046 * * * \\
(0.010)\end{array}$ & $\begin{array}{c}0.120 * * * \\
(0.027)\end{array}$ & $\begin{array}{c}0.044 * * * \\
(0.010)\end{array}$ \\
\hline Firm age & $\begin{array}{c}0.001 \\
(0.001)\end{array}$ & $\begin{array}{c}0.000 \\
(0.000)\end{array}$ & $\begin{array}{c}0.004^{* * *} \\
(0.001)\end{array}$ & $\begin{array}{c}0.001^{* * * *} \\
(0.000)\end{array}$ & $\begin{array}{c}0.003 * * \\
(0.001)\end{array}$ & $\begin{array}{c}0.001 * * \\
(0.000)\end{array}$ \\
\hline Firm use of ICT & $\begin{array}{c}0.944^{* * * *} \\
(0.053)\end{array}$ & $\begin{array}{c}0.337 * * * \\
(0.018)\end{array}$ & $\begin{array}{c}0.960 * * * \\
(0.050)\end{array}$ & $\begin{array}{c}0.354^{* * *} \\
(0.017)\end{array}$ & $\begin{array}{c}0.966 * * * \\
(0.051)\end{array}$ & $\begin{array}{c}0.355 * * * \\
(0.017)\end{array}$ \\
\hline Skilled/Total production workers & $\begin{array}{c}-0.179 * * \\
(0.084)\end{array}$ & $\begin{array}{c}-0.063^{* *} \\
(0.029)\end{array}$ & $\begin{array}{c}-0.290 * * * \\
(0.074)\end{array}$ & $\begin{array}{c}-0.107 * * * \\
(0.027)\end{array}$ & $\begin{array}{c}-0.275 * * * \\
(0.076)\end{array}$ & $\begin{array}{c}-0.101^{* * *} \\
(0.028)\end{array}$ \\
\hline Non-production/Total employment & $\begin{array}{l}-0.123 \\
(0.127)\end{array}$ & $\begin{array}{l}-0.043 \\
(0.045)\end{array}$ & $\begin{array}{c}-0.300 * * \\
(0.124)\end{array}$ & $\begin{array}{c}-0.111^{* *} \\
(0.046)\end{array}$ & $\begin{array}{c}-0.307 * * \\
(0.125)\end{array}$ & $\begin{array}{c}-0.113^{* *} \\
(0.046)\end{array}$ \\
\hline $\operatorname{Ln}(G D P C)$ & & & $\begin{array}{c}0.222 * * * \\
(0.046)\end{array}$ & $\begin{array}{c}0.082 * * * \\
(0.017)\end{array}$ & $\begin{array}{c}0.034 \\
(0.054)\end{array}$ & $\begin{array}{c}0.012 \\
(0.020)\end{array}$ \\
\hline $\operatorname{Ln}(G D P)$ & & & $\begin{array}{c}-0.330 * * * \\
(0.028)\end{array}$ & $\begin{array}{c}-0.121^{* * *} \\
(0.010)\end{array}$ & $\begin{array}{c}-0.347^{* * *} \\
(0.030)\end{array}$ & $\begin{array}{c}-0.127 * * * \\
(0.011)\end{array}$ \\
\hline Financial development & & & & & $\begin{array}{c}0.010^{* * * *} \\
(0.001)\end{array}$ & $\begin{array}{c}0.004^{* * * *} \\
(0.000)\end{array}$ \\
\hline Business freedom & & & & & $\begin{array}{c}0.093^{* * * *} \\
(0.016) \\
\end{array}$ & $\begin{array}{c}0.034 * * * \\
(0.006) \\
\end{array}$ \\
\hline Country-specific effects & \multicolumn{2}{|c|}{ Yes } & \multicolumn{2}{|c|}{ No } & \multicolumn{2}{|c|}{ No } \\
\hline$N$ & \multicolumn{2}{|c|}{4386} & \multicolumn{2}{|c|}{4386} & \multicolumn{2}{|c|}{4386} \\
\hline
\end{tabular}

Notes: Statistical significance: $*=10 \% ; * *=5 \% ; * * *=1 \%$. Robust standard errors are in parentheses. 
Table 3: Firms’ Export Intensity (Fractional Logit Model)

\begin{tabular}{|c|c|c|c|c|c|c|}
\hline & \multicolumn{2}{|c|}{$(1)$} & \multicolumn{2}{|c|}{$(2)$} & \multicolumn{2}{|c|}{ (3) } \\
\hline & Coefficients & $\begin{array}{c}\text { Marginal } \\
\text { effects }\end{array}$ & Coefficients & $\begin{array}{c}\text { Marginal } \\
\text { effects }\end{array}$ & Coefficients & $\begin{array}{c}\text { Marginal } \\
\text { effects }\end{array}$ \\
\hline Foreign ownership & $\begin{array}{c}1.531^{* * *} \\
(0.207)\end{array}$ & $\begin{array}{c}0.123^{* * * *} \\
(0.018)\end{array}$ & $\begin{array}{c}1.701 * * * \\
(0.163)\end{array}$ & $\begin{array}{c}0.179 * * * \\
(0.018)\end{array}$ & $\begin{array}{c}1.474 * * * \\
(0.165)\end{array}$ & $\begin{array}{c}0.154 * * * \\
(0.018)\end{array}$ \\
\hline Government ownership & $\begin{array}{c}-1.012 * * * \\
(0.281)\end{array}$ & $\begin{array}{c}-0.082 * * * \\
(0.023)\end{array}$ & $\begin{array}{c}-1.232 * * * \\
(0.281)\end{array}$ & $\begin{array}{c}-0.130 * * * \\
(0.030)\end{array}$ & $\begin{array}{c}-1.218 * * * \\
(0.277)\end{array}$ & $\begin{array}{c}-0.127 * * * \\
(0.029)\end{array}$ \\
\hline Firm size & $\begin{array}{c}0.082 * * * \\
(0.012)\end{array}$ & $\begin{array}{c}0.007 * * * \\
(0.001)\end{array}$ & $\begin{array}{c}0.090 * * * \\
(0.012)\end{array}$ & $\begin{array}{c}0.009 * * * \\
(0.001)\end{array}$ & $\begin{array}{c}0.085^{* * * *} \\
(0.012)\end{array}$ & $\begin{array}{c}0.009 * * * \\
(0.001)\end{array}$ \\
\hline Firm age & $\begin{array}{c}-0.005^{* *} \\
(0.002)\end{array}$ & $\begin{array}{c}-0.000^{* *} \\
(0.000)\end{array}$ & $\begin{array}{l}-0.002 \\
(0.002)\end{array}$ & $\begin{array}{l}-0.000 \\
(0.000)\end{array}$ & $\begin{array}{l}-0.003 \\
(0.002)\end{array}$ & $\begin{array}{l}-0.000 \\
(0.000)\end{array}$ \\
\hline Firm use of ICT & $\begin{array}{c}1.133^{* * * *} \\
(0.076)\end{array}$ & $\begin{array}{c}0.103^{* * * *} \\
(0.009)\end{array}$ & $\begin{array}{c}1.228 * * * \\
(0.075)\end{array}$ & $\begin{array}{c}0.145^{* * * *} \\
(0.009)\end{array}$ & $\begin{array}{c}1.227 * * * \\
(0.075)\end{array}$ & $\begin{array}{c}0.144 * * * \\
(0.009)\end{array}$ \\
\hline Skilled/Total production workers & $\begin{array}{c}0.153 \\
(0.129)\end{array}$ & $\begin{array}{c}0.012 \\
(0.010)\end{array}$ & $\begin{array}{c}-0.039 \\
(0.119)\end{array}$ & $\begin{array}{l}-0.004 \\
(0.013)\end{array}$ & $\begin{array}{c}-0.015 \\
(0.122)\end{array}$ & $\begin{array}{l}-0.002 \\
(0.013)\end{array}$ \\
\hline Non-production/Total employment & $\begin{array}{c}-1.067 * * * \\
(0.213)\end{array}$ & $\begin{array}{c}-0.086 * * * \\
(0.017)\end{array}$ & $\begin{array}{c}-1.282 * * * \\
(0.220)\end{array}$ & $\begin{array}{c}-0.135 * * * \\
(0.023)\end{array}$ & $\begin{array}{c}-1.298 * * * \\
(0.220)\end{array}$ & $\begin{array}{c}-0.135 * * * \\
(0.023)\end{array}$ \\
\hline $\operatorname{Ln}(G D P C)$ & & & $\begin{array}{c}0.230 * * * \\
(0.061)\end{array}$ & $\begin{array}{c}0.024^{* * *} \\
(0.006)\end{array}$ & $\begin{array}{c}-0.023 \\
(0.077)\end{array}$ & $\begin{array}{c}-0.002 \\
(0.008)\end{array}$ \\
\hline $\operatorname{Ln}(G D P)$ & & & $\begin{array}{c}-0.483 * * * \\
(0.040)\end{array}$ & $\begin{array}{c}-0.051 * * * \\
(0.004)\end{array}$ & $\begin{array}{c}-0.490 * * * \\
(0.045)\end{array}$ & $\begin{array}{c}-0.051 * * * \\
(0.005)\end{array}$ \\
\hline Financial development & & & & & $\begin{array}{c}0.015 * * * \\
(0.002)\end{array}$ & $\begin{array}{c}0.002 * * * \\
(0.000)\end{array}$ \\
\hline Business freedom & & & & & $\begin{array}{c}0.157 * * * \\
(0.029)\end{array}$ & $\begin{array}{c}0.016 * * * \\
(0.003)\end{array}$ \\
\hline Country-specific effects & \multicolumn{2}{|c|}{ Yes } & \multicolumn{2}{|c|}{ No } & \multicolumn{2}{|c|}{ No } \\
\hline$N$ & \multicolumn{2}{|c|}{43866} & \multicolumn{2}{|c|}{4386} & \multicolumn{2}{|c|}{4386} \\
\hline
\end{tabular}

Notes: Statistical significance: $*=10 \% ; * *=5 \% ; * * *=1 \%$. Robust standard errors are in parentheses. 
Table 4: Firms’ Decision to Export by Country (Probit Model, Coefficients)

\begin{tabular}{|c|c|c|c|c|c|c|c|}
\hline & $(1)$ & $(2)$ & $(3)$ & $(4)$ & $(5)$ & $(6)$ & $(7)$ \\
\hline & Algeria & Egypt & Jordan & Lebanon & Morocco & Syria & Yemen \\
\hline Foreign ownership & $\begin{array}{c}0.388 \\
(0.532)\end{array}$ & $\begin{array}{c}1.167 * * * \\
(0.312)\end{array}$ & $\begin{array}{c}1.034 * \\
(0.542)\end{array}$ & $\begin{array}{c}-0.484 \\
(0.729)\end{array}$ & $\begin{array}{c}0.637 * * \\
(0.317)\end{array}$ & $\begin{array}{c}0.130 \\
(0.671)\end{array}$ & $\begin{array}{c}6.755 * * * \\
(2.339)\end{array}$ \\
\hline Government ownership & & $\begin{array}{c}0.132 \\
(0.258)\end{array}$ & $\begin{array}{c}-3.504 \\
(3.164)\end{array}$ & & $\begin{array}{c}1.514 \\
(1.077)\end{array}$ & $\begin{array}{c}-2.060 * * * \\
(0.636)\end{array}$ & $\begin{array}{c}-2.361^{* * *} \\
(0.910)\end{array}$ \\
\hline Firm size & $\begin{array}{c}0.326 * * * \\
(0.098)\end{array}$ & $\begin{array}{c}0.094 * * * \\
(0.022)\end{array}$ & $\begin{array}{l}0.169 * \\
(0.091)\end{array}$ & $\begin{array}{c}0.111 \\
(0.169)\end{array}$ & $\begin{array}{c}0.427 * * * \\
(0.153)\end{array}$ & $\begin{array}{c}0.445 * * * \\
(0.102)\end{array}$ & $\begin{array}{c}0.576 * * * \\
(0.161)\end{array}$ \\
\hline Firm age & $\begin{array}{l}-0.003 \\
(0.008)\end{array}$ & $\begin{array}{l}-0.001 \\
(0.002)\end{array}$ & $\begin{array}{c}0.002 \\
(0.007)\end{array}$ & $\begin{array}{c}0.004 \\
(0.003)\end{array}$ & $\begin{array}{c}-0.030 * * * \\
(0.008)\end{array}$ & $\begin{array}{c}0.008 * * \\
(0.004)\end{array}$ & $\begin{array}{l}-0.005 \\
(0.015)\end{array}$ \\
\hline Firm use of ICT & $\begin{array}{c}0.552^{* * *} \\
(0.205)\end{array}$ & $\begin{array}{c}1.152^{* * *} \\
(0.075)\end{array}$ & $\begin{array}{c}1.339 * * * \\
(0.171)\end{array}$ & $\begin{array}{c}0.547^{* * * *} \\
(0.169)\end{array}$ & $\begin{array}{c}0.322 \\
(0.290)\end{array}$ & $\begin{array}{c}0.539 * * * \\
(0.099)\end{array}$ & $\begin{array}{c}0.832 * * \\
(0.348)\end{array}$ \\
\hline Skilled/Total production workers & $\begin{array}{l}-0.042 \\
(0.264)\end{array}$ & $\begin{array}{l}-0.154 \\
(0.138)\end{array}$ & $\begin{array}{c}0.301 \\
(0.325)\end{array}$ & $\begin{array}{c}-0.103 \\
(0.251)\end{array}$ & $\begin{array}{l}-0.313 \\
(0.408)\end{array}$ & $\begin{array}{c}-0.395 * * \\
(0.170)\end{array}$ & $\begin{array}{c}0.096 \\
(0.411)\end{array}$ \\
\hline Non-production/Total employment & $\begin{array}{l}-0.529 \\
(0.755) \\
\end{array}$ & $\begin{array}{c}0.191 \\
(0.197) \\
\end{array}$ & $\begin{array}{c}-0.322 \\
(0.360) \\
\end{array}$ & $\begin{array}{l}-0.477 \\
(0.402) \\
\end{array}$ & $\begin{array}{c}-0.817 \\
(0.710) \\
\end{array}$ & $\begin{array}{c}0.032 \\
(0.289) \\
\end{array}$ & $\begin{array}{c}0.763 \\
(1.056) \\
\end{array}$ \\
\hline$N$ & 561 & 2029 & 342 & 275 & 119 & 762 & 224 \\
\hline
\end{tabular}

Notes: Statistical significance: $*=10 \% ; * *=5 \% ; * * *=1 \%$. Robust standard errors are in parentheses. Government ownership perfectly predicts nonexporting Algerian firms in the dataset. There are no Lebanese firms with government ownership in the dataset. 
Table 5: Firms’ Decision to Export by Country (Probit Model, Marginal Effects)

\begin{tabular}{|c|c|c|c|c|c|c|c|}
\hline & (1) & $(2)$ & (3) & (4) & (5) & (6) & (7) \\
\hline & Algeria & Egypt & Jordan & Lebanon & Morocco & Syria & Y Yemen \\
\hline Foreign ownership & $\begin{array}{c}0.026 \\
(0.035)\end{array}$ & $\begin{array}{c}0.404^{* * *} \\
(0.109)\end{array}$ & $\begin{array}{l}0.407 * \\
(0.212)\end{array}$ & $\begin{array}{l}-0.169 \\
(0.254)\end{array}$ & $\begin{array}{c}0.243 * * \\
(0.121)\end{array}$ & $\begin{array}{c}0.050 \\
(0.256)\end{array}$ & $\begin{array}{c}0.451^{* *} \\
(0.220)\end{array}$ \\
\hline Government ownership & & $\begin{array}{c}0.046 \\
(0.089)\end{array}$ & $\begin{array}{c}-1.381 \\
(1.251)\end{array}$ & & $\begin{array}{c}0.579 \\
(0.411)\end{array}$ & $\begin{array}{c}-0.587^{* * *} \\
(0.062)\end{array}$ & $\begin{array}{c}-0.158 * \\
(0.082)\end{array}$ \\
\hline Firm size & $\begin{array}{c}0.022 * * * \\
(0.008)\end{array}$ & $\begin{array}{c}0.033 * * * \\
(0.008)\end{array}$ & $\begin{array}{l}0.066 * \\
(0.036)\end{array}$ & $\begin{array}{c}0.039 \\
(0.059)\end{array}$ & $\begin{array}{c}0.163 * * * \\
(0.054)\end{array}$ & $\begin{array}{c}0.170 * * * \\
(0.038)\end{array}$ & $\begin{array}{c}0.038 * * \\
(0.018)\end{array}$ \\
\hline Firm age & $\begin{array}{l}-0.000 \\
(0.001)\end{array}$ & $\begin{array}{l}-0.000 \\
(0.001)\end{array}$ & $\begin{array}{c}0.001 \\
(0.003)\end{array}$ & $\begin{array}{c}0.001 \\
(0.001)\end{array}$ & $\begin{array}{c}-0.011 * * * \\
(0.003)\end{array}$ & $\begin{array}{c}0.003^{* *} \\
(0.001)\end{array}$ & $\begin{array}{l}-0.000 \\
(0.001)\end{array}$ \\
\hline Firm use of ICT & $\begin{array}{c}0.047 * * \\
(0.020)\end{array}$ & $\begin{array}{c}0.410 * * * \\
(0.025)\end{array}$ & $\begin{array}{c}0.492 * * * \\
(0.055)\end{array}$ & $\begin{array}{c}0.191^{* * *} \\
(0.058)\end{array}$ & $\begin{array}{c}0.122 \\
(0.108)\end{array}$ & $\begin{array}{c}0.204^{* * *} \\
(0.037)\end{array}$ & $\begin{array}{l}0.090^{*} \\
(0.047)\end{array}$ \\
\hline Skilled/Total production workers & $\begin{array}{l}-0.003 \\
(0.018)\end{array}$ & $\begin{array}{l}-0.053 \\
(0.048)\end{array}$ & $\begin{array}{c}0.118 \\
(0.128)\end{array}$ & $\begin{array}{l}-0.036 \\
(0.088)\end{array}$ & $\begin{array}{l}-0.120 \\
(0.155)\end{array}$ & $\begin{array}{c}-0.151^{* *} \\
(0.065)\end{array}$ & $\begin{array}{c}0.006 \\
(0.027)\end{array}$ \\
\hline Non-production/Total employment & $\begin{array}{l}-0.036 \\
(0.050) \\
\end{array}$ & $\begin{array}{c}0.066 \\
(0.068) \\
\end{array}$ & $\begin{array}{l}-0.127 \\
(0.142) \\
\end{array}$ & $\begin{array}{l}-0.167 \\
(0.141) \\
\end{array}$ & $\begin{array}{c}-0.312 \\
(0.273) \\
\end{array}$ & $\begin{array}{c}0.012 \\
(0.110) \\
\end{array}$ & $\begin{array}{c}0.051 \\
(0.065) \\
\end{array}$ \\
\hline$N$ & 561 & 2029 & 342 & 275 & 119 & 762 & 224 \\
\hline
\end{tabular}

Notes: Statistical significance: $*=10 \% ; * *=5 \% ; * * *=1 \%$. Robust standard errors are in parentheses. Government ownership perfectly predicts nonexporting Algerian firms in the dataset. There are no Lebanese firms with government ownership in the dataset. 
Table 6: Firms’ Export Intensity by Country (Fractional Logit Model, Coefficients)

\begin{tabular}{|c|c|c|c|c|c|c|c|}
\hline & (1) & $(2)$ & (3) & (4) & (5) & (6) & (7) \\
\hline & Algeria & Egypt & Jordan & Lebanon & Morocco & Syria & Y Yemen \\
\hline Foreign ownership & $\begin{array}{c}-1.630 \\
(0.993)\end{array}$ & $\begin{array}{c}1.431^{* * *} \\
(0.324)\end{array}$ & $\begin{array}{c}2.581^{* * * *} \\
(0.734)\end{array}$ & $\begin{array}{c}0.689 \\
(1.000)\end{array}$ & $\begin{array}{c}-0.346 \\
(0.529)\end{array}$ & $\begin{array}{c}1.063 \\
(0.829)\end{array}$ & $\begin{array}{c}9.032 * * \\
(3.870)\end{array}$ \\
\hline Government ownership & & $\begin{array}{l}-0.482^{*} \\
(0.291)\end{array}$ & $\begin{array}{l}-4.531 \\
(2.869)\end{array}$ & & $\begin{array}{c}0.362 \\
(0.605)\end{array}$ & $\begin{array}{c}-2.304^{* * * *} \\
(0.528)\end{array}$ & $\begin{array}{l}-7.950^{*} \\
(4.826)\end{array}$ \\
\hline Firm size & $\begin{array}{c}0.473 * * \\
(0.194)\end{array}$ & $\begin{array}{c}0.061^{* * *} \\
(0.011)\end{array}$ & $\begin{array}{c}0.267 * * * \\
(0.100)\end{array}$ & $\begin{array}{c}0.076 \\
(0.114)\end{array}$ & $\begin{array}{c}0.402 * * \\
(0.199)\end{array}$ & $\begin{array}{c}0.112 * * \\
(0.053)\end{array}$ & $\begin{array}{c}0.299 \\
(0.217)\end{array}$ \\
\hline Firm age & $\begin{array}{c}0.026 * * \\
(0.012)\end{array}$ & $\begin{array}{l}-0.007 \\
(0.004)\end{array}$ & $\begin{array}{c}-0.031 * * * \\
(0.009)\end{array}$ & $\begin{array}{c}0.004 \\
(0.003)\end{array}$ & $\begin{array}{c}-0.081 * * * \\
(0.014)\end{array}$ & $\begin{array}{c}0.006 \\
(0.004)\end{array}$ & $\begin{array}{c}-0.024 \\
(0.048)\end{array}$ \\
\hline Firm use of ICT & $\begin{array}{c}1.128 \\
(0.836)\end{array}$ & $\begin{array}{c}1.587 * * * \\
(0.125)\end{array}$ & $\begin{array}{c}1.385^{* * * *} \\
(0.272)\end{array}$ & $\begin{array}{c}0.438 * * \\
(0.190)\end{array}$ & $\begin{array}{c}0.456 \\
(0.465)\end{array}$ & $\begin{array}{c}0.714^{* * * *} \\
(0.131)\end{array}$ & $\begin{array}{l}1.932 * * \\
(0.859)\end{array}$ \\
\hline Skilled/Total production workers & $\begin{array}{l}-0.313 \\
(1.202)\end{array}$ & $\begin{array}{c}0.199 \\
(0.242)\end{array}$ & $\begin{array}{c}0.731 \\
(0.475)\end{array}$ & $\begin{array}{c}0.125 \\
(0.278)\end{array}$ & $\begin{array}{l}-0.018 \\
(0.651)\end{array}$ & $\begin{array}{c}0.003 \\
(0.217)\end{array}$ & $\begin{array}{c}0.269 \\
(1.039)\end{array}$ \\
\hline Non-production/Total employment & $\begin{array}{l}-2.377 \\
(3.628) \\
\end{array}$ & $\begin{array}{l}-0.425 \\
(0.338) \\
\end{array}$ & $\begin{array}{l}-0.837 \\
(0.536) \\
\end{array}$ & $\begin{array}{l}-0.594 \\
(0.520) \\
\end{array}$ & $\begin{array}{c}-6.549 * * * \\
(1.685) \\
\end{array}$ & $\begin{array}{c}-1.058 * * * \\
(0.406) \\
\end{array}$ & $\begin{array}{c}0.262 \\
(1.696) \\
\end{array}$ \\
\hline$N$ & 561 & 2029 & 342 & 275 & 119 & 762 & 224 \\
\hline
\end{tabular}

Notes: Statistical significance: $*=10 \% ; * *=5 \% ; * * *=1 \%$. Robust standard errors are in parentheses. Government ownership perfectly predicts nonexporting Algerian firms in the dataset. There are no Lebanese firms with government ownership in the dataset. 
Table 7: Firms’ Export Intensity by Country (Fractional Logit Model, Marginal Effects)

\begin{tabular}{|c|c|c|c|c|c|c|c|}
\hline & $(1)$ & $(2)$ & (3) & $(4)$ & (5) & $(6)$ & $(7)$ \\
\hline & Algeria & Egypt & Jordan & Lebanon & Morocco & Syria & Yemen \\
\hline Foreign ownership & $\begin{array}{c}-0.006 \\
(0.005)\end{array}$ & $\begin{array}{c}0.118 * * * \\
(0.028)\end{array}$ & $\begin{array}{c}0.515^{* * *} \\
(0.158)\end{array}$ & $\begin{array}{c}0.133 \\
(0.193)\end{array}$ & $\begin{array}{c}-0.069 \\
(0.106)\end{array}$ & $\begin{array}{c}0.195 \\
(0.152)\end{array}$ & $\begin{array}{l}0.129 * \\
(0.067)\end{array}$ \\
\hline Government ownership & & $\begin{array}{l}-0.040 \\
(0.024)\end{array}$ & $\begin{array}{c}-0.904 \\
(0.568)\end{array}$ & & $\begin{array}{c}0.072 \\
(0.116)\end{array}$ & $\begin{array}{c}-0.215^{* * *} \\
(0.019)\end{array}$ & $\begin{array}{l}-0.113 \\
(0.080)\end{array}$ \\
\hline Firm size & $\begin{array}{l}0.002 * \\
(0.001)\end{array}$ & $\begin{array}{c}0.005^{* * * *} \\
(0.001)\end{array}$ & $\begin{array}{c}0.053 * * \\
(0.021)\end{array}$ & $\begin{array}{c}0.015 \\
(0.022)\end{array}$ & $\begin{array}{l}0.080 * \\
(0.045)\end{array}$ & $\begin{array}{c}0.021 * * \\
(0.010)\end{array}$ & $\begin{array}{c}0.004 \\
(0.004)\end{array}$ \\
\hline Firm age & $\begin{array}{l}0.000^{*} \\
(0.000)\end{array}$ & $\begin{array}{l}-0.001 \\
(0.000)\end{array}$ & $\begin{array}{c}-0.006 * * * \\
(0.002)\end{array}$ & $\begin{array}{c}0.001 \\
(0.001)\end{array}$ & $\begin{array}{c}-0.016 * * * \\
(0.003)\end{array}$ & $\begin{array}{c}0.001 \\
(0.001)\end{array}$ & $\begin{array}{c}-0.000 \\
(0.001)\end{array}$ \\
\hline Firm use of ICT & $\begin{array}{c}0.005 \\
(0.005)\end{array}$ & $\begin{array}{c}0.164 * * * \\
(0.014)\end{array}$ & $\begin{array}{c}0.271 * * * \\
(0.046)\end{array}$ & $\begin{array}{c}0.084^{* *} \\
(0.036)\end{array}$ & $\begin{array}{c}0.092 \\
(0.095)\end{array}$ & $\begin{array}{c}0.130 * * * \\
(0.023)\end{array}$ & $\begin{array}{c}0.054 \\
(0.036)\end{array}$ \\
\hline Skilled/Total production workers & $\begin{array}{l}-0.001 \\
(0.004)\end{array}$ & $\begin{array}{c}0.016 \\
(0.020)\end{array}$ & $\begin{array}{c}0.146 \\
(0.093)\end{array}$ & $\begin{array}{c}0.024 \\
(0.054)\end{array}$ & $\begin{array}{c}-0.004 \\
(0.130)\end{array}$ & $\begin{array}{c}0.001 \\
(0.040)\end{array}$ & $\begin{array}{c}0.004 \\
(0.015)\end{array}$ \\
\hline Non-production/Total employment & $\begin{array}{l}-0.009 \\
(0.013) \\
\end{array}$ & $\begin{array}{l}-0.035 \\
(0.028) \\
\end{array}$ & $\begin{array}{l}-0.167 \\
(0.107) \\
\end{array}$ & $\begin{array}{l}-0.114 \\
(0.100) \\
\end{array}$ & $\begin{array}{c}-1.305^{* * * *} \\
(0.284) \\
\end{array}$ & $\begin{array}{c}-0.194^{* * *} \\
(0.074) \\
\end{array}$ & $\begin{array}{r}0.004 \\
(0.023) \\
\end{array}$ \\
\hline$N$ & 561 & 2029 & 342 & 275 & 119 & 762 & 224 \\
\hline
\end{tabular}

Notes: Statistical significance: $*=10 \% ; * *=5 \% ; * * *=1 \%$. Robust standard errors are in parentheses. Government ownership perfectly predicts nonexporting Algerian firms in the dataset. There are no Lebanese firms with government ownership in the dataset. 


\section{Appendix}

Table A1: Results from alternative empirical specifications.

\begin{tabular}{|c|c|c|c|c|}
\hline & \multicolumn{2}{|c|}{$(1)$} & \multicolumn{2}{|c|}{ (2) } \\
\hline & \multicolumn{2}{|c|}{ Probit model } & \multicolumn{2}{|c|}{ Fractional logit model } \\
\hline & Coefficients & $\begin{array}{c}\text { Marginal } \\
\text { effects }\end{array}$ & Coefficients & $\begin{array}{c}\text { Marginal } \\
\text { effects }\end{array}$ \\
\hline Foreign ownership & $\begin{array}{c}0.858 * * * \\
(0.173)\end{array}$ & $\begin{array}{c}0.281^{* * *} \\
(0.057)\end{array}$ & $\begin{array}{c}1.386 * * * \\
(0.212)\end{array}$ & $\begin{array}{c}0.087 * * * \\
(0.014)\end{array}$ \\
\hline Government ownership & $\begin{array}{l}-0.075 \\
(0.232)\end{array}$ & $\begin{array}{c}-0.024 \\
(0.076)\end{array}$ & $\begin{array}{c}-0.618^{*} \\
(0.326)\end{array}$ & $\begin{array}{c}-0.039 * \\
(0.021)\end{array}$ \\
\hline Firm size & $\begin{array}{c}0.107 * * * \\
(0.024)\end{array}$ & $\begin{array}{c}0.035^{* * *} \\
(0.008)\end{array}$ & $\begin{array}{c}0.075^{* * *} \\
(0.011)\end{array}$ & $\begin{array}{c}0.005^{* * *} \\
(0.001)\end{array}$ \\
\hline Firm age & $\begin{array}{l}-0.001 \\
(0.002)\end{array}$ & $\begin{array}{c}0.000 \\
(0.001)\end{array}$ & $\begin{array}{c}-0.009 * * * \\
(0.003)\end{array}$ & $\begin{array}{c}-0.001 * * * \\
0.000\end{array}$ \\
\hline Firm use of ICT & $\begin{array}{c}1.033^{* * *} * \\
(0.058)\end{array}$ & $\begin{array}{c}0.353 * * * \\
(0.019)\end{array}$ & $\begin{array}{c}1.438 * * * \\
(0.087)\end{array}$ & $\begin{array}{c}0.111^{* * * *} \\
(0.009)\end{array}$ \\
\hline Skilled/Total production workers & $\begin{array}{l}-0.133 \\
(0.093)\end{array}$ & $\begin{array}{c}-0.044 \\
(0.030)\end{array}$ & $\begin{array}{c}0.162 \\
(0.159)\end{array}$ & $\begin{array}{c}0.010 \\
(0.010)\end{array}$ \\
\hline Non-production/Total employment & $\begin{array}{l}-0.009 \\
(0.140) \\
\end{array}$ & $\begin{array}{c}-0.003 \\
(0.046) \\
\end{array}$ & $\begin{array}{c}-0.493^{* *} \\
(0.226) \\
\end{array}$ & $\begin{array}{c}-0.031^{* *} \\
(0.014) \\
\end{array}$ \\
\hline Country-specific effects & \multicolumn{2}{|c|}{ Yes } & \multicolumn{2}{|c|}{ Yes } \\
\hline Sector-specific effects & \multicolumn{2}{|c|}{ Yes } & \multicolumn{2}{|c|}{ Yes } \\
\hline$N$ & \multicolumn{2}{|c|}{4386} & \multicolumn{2}{|c|}{4386} \\
\hline
\end{tabular}

Notes: Statistical significance: ${ }^{*}=10 \% ;{ }^{* *}=5 \% ;{ }^{* * *}=1 \%$. Robust standard errors are in parentheses. 